\title{
RADIATION-INDUCED SEGREGATION AND VOID SWELLING IN 304 STAINLESS STEEL
}

by

\author{
T. R. Allen, J. I. Cole
}

RECEIVED

E. A. Kenik

JUL 102000
OSTI

Engineering Division

Argonne National Laboratory-West

P. O. Box 2528

Idaho Falls, ID 83403-2528

\begin{tabular}{|l|}
\hline $\begin{array}{l}\text { The submitted manuscript has been } \\
\text { created by the University of Chicago } \\
\text { as Operator of Argonne National } \\
\text { Laboratory ("Argonne”) under } \\
\text { contract No. W-31-109-ENG-38 with } \\
\text { the U. S. Department of Energy. } \\
\text { The U.S. Government retains for } \\
\text { itself, and others acting on its behalf, } \\
\text { a paid-up nonexclusive, irrevocable } \\
\text { worldwide license in said article to } \\
\text { reproduce, prepare derivative works, } \\
\text { distribute copies to the public, and } \\
\text { perform publicly and display publicly, } \\
\text { by or on behalf of the Government. }\end{array}$ \\
\hline
\end{tabular}

$20^{\text {th }}$ Symposium on Effects of Radiation on Materials

Williamsburg, VA

June 6-8, 2000

*Work supported by the U.S. Department of Energy, Office of Nuclear Energy, Science and Technology, under Contract W-31-109-ENG-38. 


\section{DISCLAIMER}

This report was prepared as an account of work sponsored by an agency of the United States Government. Neither the United States Government nor any agency thereof, nor any of their employees, make any warranty, express or implied, or assumes any legal liability or responsibility for the accuracy, completeness, or usefulness of any information, apparatus, product, or process disclosed, or represents that its use would not infringe privately owned rights. Reference herein to any specific commercial product, process, or service by trade name, trademark, manufacturer, or otherwise does not necessarily constitute or imply its endorsement, recommendation, or favoring by the United States Government or any agency thereof. The views and opinions of authors expressed herein do not necessarily state or reflect those of the United States Government or any agency thereof. 


\section{DISCLAIMER}

Portions of this document may be illegible in electronic image products. Images are produced from the best available original document. 


\section{Preliminary Program and Registration Information}

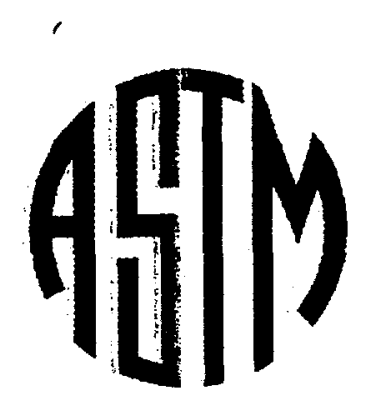

\section{$20^{\text {th }}$ Symposium on Effects of Radiation on Materials}

Sponsored by Committee E-10 on Nuclear Technology and Applications

June 6-8, 2000

Williamsburg Hospitality House

Williamsburg, Virginia 
T. R. Allen, ${ }^{1}$ J. I. Cole, ${ }^{1}$ and E. A. Kenik ${ }^{2}$

\title{
Radiation-Induced Segregation and Void Swelling in 304 Stainless Steel
}

Reference: Allen, T. R., Cole, J. I., and Kenik, E. A., "Radiation-Induced Segregation and Void Swelling in 304 Stainless Steel," Effects of Radiation on Materials: $20^{\text {th }}$ International Symposium, ASTM STP 1405, S. T. Rosinski, M. L. Grossbeck, T. R. Allen, and A. S. Kumar, Eds., American Society for Testing and Materials, West Conshohocken, PA, 2002.

\begin{abstract}
:
Void swelling and radiation-induced segregation have been measured in 304 stainless steel. Samples were irradiated in the outer regions of the EBR-II reactor where displacement rates of $2.0 \times 10^{-8}$ and $6.6 \times 10^{-8} \mathrm{dpa} / \mathrm{s}$ are comparable to those in pressurized water reactor components. Samples were irradiated at temperatures from $371-390^{\circ} \mathrm{C}$ to total doses of up to $20 \mathrm{dpa}$. Void swelling reached a maximum of $2 \%$ at $20 \mathrm{dpa}$. Nickel enrichment and chromium depletion of up to of 20 at $\%$ and 12 at $\%$ respectively were measured. Both void swelling and radiation-induced segregation were dependent on dose rate, increasing as the dose rate decreased. Grain boundary compositions were measured both near and in areas free of precipitates. The presence of a precipitate significantly changes the grain boundary compositions near the precipitate.
\end{abstract}

Keywords: void swelling, radiation-induced segregation, austenitic steels

\footnotetext{
${ }^{1}$ Argonne National Laboratory-West, PO Box 2528, Idaho Falls, ID 83403-2528.

${ }^{2}$ Metals and Ceramics Division, Oak Ridge National Laboratory, Oak Ridge, TN 37831
} 


\section{Introduction}

For operating nuclear reactors, many core components are constructed from 304 stainless steel [1]. Performance of 304 stainless steel under long-time, low dose rate irradiation is important to extended life operation. The dose rates for typical pressurized water reactor (PWR) components range from about $1.4 \times 10^{-7} \mathrm{dpa} / \mathrm{s}$ for components in the inner core region to $1.4 \times 10^{-10} \mathrm{dpa} / \mathrm{s}$ for the core barrel (these displacement rates are calculated using fast neutron fluences from [2] converted to dpa using $0.7 \times 10^{21} \mathrm{n} / \mathrm{cm}^{2}=1$ dpa [3]), with thicker components reaching temperatures up to $400^{\circ} \mathrm{C}$ [4].

As part of the EBR-II reactor materials surveillance (SURV) program [5-9], test samples of 304 stainless steel were placed into EBR-II in 1965, with the intention of determining microstructural, corrosion, and mechanical property changes due to irradiation and thermal aging. The peak displacement rate for the materials in the SURV subassemblies was approximately $6.5 \times 10^{-8} \mathrm{dpa} / \mathrm{s}$. This displacement rate is about two orders of magnitude lower than used in a typical accelerated reactor materials test but within the range of displacement rates experienced by commercial light-water reactor (LWR) core components [4].

Following shutdown of the EBR-II reactor, surveillance test samples constructed of 304 stainless steel were retrieved to determine the effect of low dose rate irradiation on mechanical properties and microstructure. In addition to the SURV specimens, a large quantity of hexagonal duct material, made of 304 stainless steel with a thickness of approximately $1 \mathrm{~mm}$, was retrieved from the reflector region of the EBR-II. These EBR-II components were irradiated at temperatures greater than most PWR components. Even so, the material is valuable for understanding life extension problems in PWRs. Test samples can be irradiated in PWRs at operating temperatures, but to get to the high doses expected at end of life, the samples must be irradiated at a dose rate higher than experienced by actual core components. The EBR-II material is irradiated at a representative dose rate, but at a slightly elevated temperature. The scenario is illustrated in figure 1. Because the development of irradiated microstructure is both temperature and dose rate dependent, a high temperature or high dose rate test by itself is not entirely representative. An analysis that includes both high dose rate (operating PWR) and high temperature (EBR-II) data provides a greater opportunity to identify and understand mechanisms of radiation damage.

This work reports on the swelling, microchemical, and microstructural changes that occur in 304 stainless steel irradiated at temperatures from $371-390^{\circ} \mathrm{C}$. Samples were irradiated at dose rates ranging from $2.0 \times 10^{-8}$ and $6.6 \times 10^{-8} \mathrm{dpa} / \mathrm{s}$ to doses of $20 \mathrm{dpa}$. 


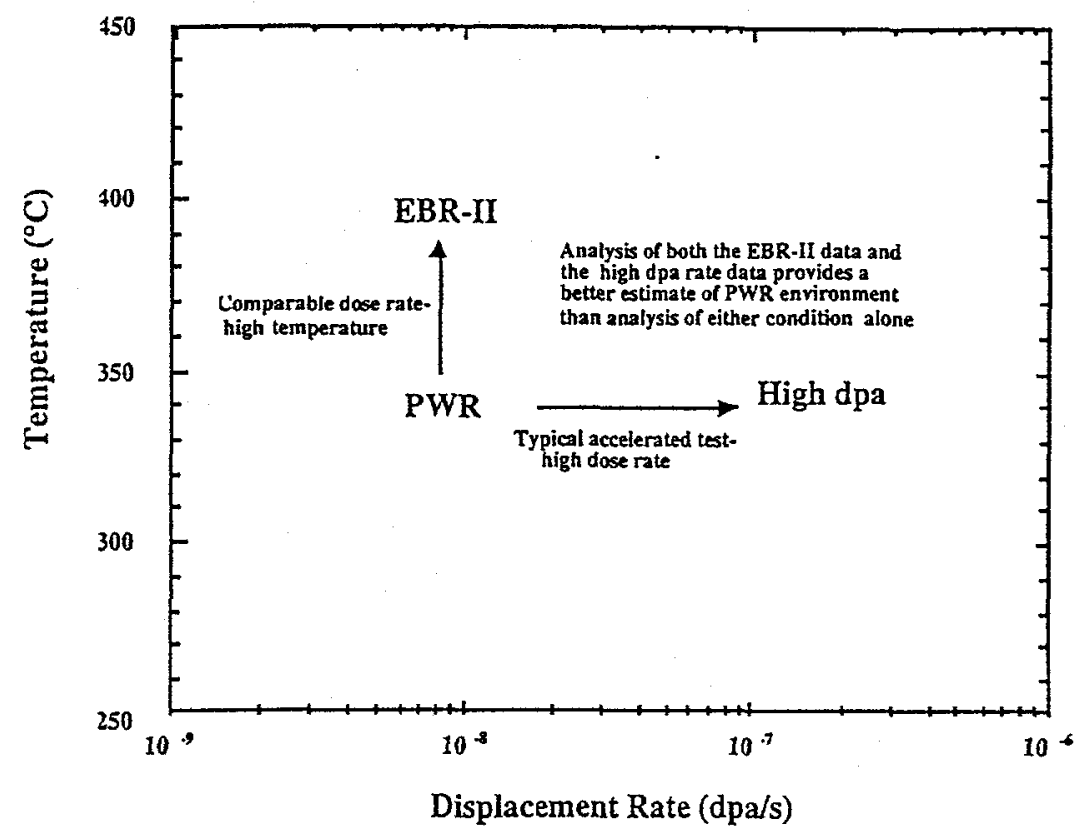

Figure 1-Analyzing both higher temperature and higher dose rate samples provides a better understanding of actual $P W R$ materials aging.

\section{Experiment}

Two analyses were performed on the 304 stainless steel samples: bulk swelling was measured using immersion density and microstructural and microchemical characterization was performed using transmission electron microscopy. Density samples were examined from six different surveillance (SURV) subassemblies irradiated in row 12 of EBR-II and from reflector hex cans irradiated in row 10 and 14 of EBR-II. SURV density specimens were prepared by slicing an approximately $1 \mathrm{~mm}$ thick disk from the $1.11 \mathrm{~cm}$ SURV hardness/corrosion specimens (see figure 2). For the reflector subassemblies, three-quarter inch $(1.9 \mathrm{~cm}$.) diameter samples were punched at selected locations of the $1 \mathrm{~mm}$ thick hex cans using a remotely controlled hydraulic punch.

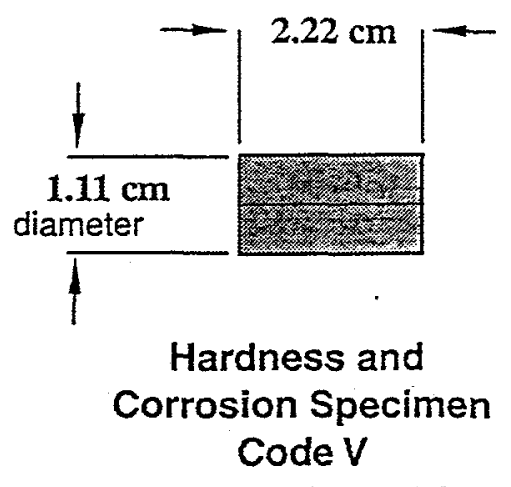

Figure 2-Surveillance (SURV) hardness specimen 
Samples for microstructural and microchemical analysis were prepared from the density samples. The density disks were thinned in a hot cell to about $250 \mu \mathrm{m}$ by mounting and grinding using standard metallographic sample preparation techniques. Three millimeter TEM sample blanks were then punched from these thinned disks using a special mechanical punch developed for hot cell use. TEM sample blanks were electropolished at $-30^{\circ} \mathrm{C}$ using a $5 \%$ perchloric acid $/ 95 \%$ methanol solution until electron transparent. Grain boundary compositions were measured using a Phillips CM200 FEGSTEM with an EMiSPEC X-ray analysis system. Other microstructural characterization was performed using a JEOL 2010 transmission electron microscope.

SURV specimens were irradiated to doses from 0.25 to 20 dpa at temperatures ranging from $371-390^{\circ} \mathrm{C}$. The dose rate, temperature, and final dose of each SURV density specimen depended on its axial location in the surveillance subassembly. The displacement rates varied from $3.1 \times 10^{-8} \mathrm{dpa} / \mathrm{s}$ to $6.5 \times 10^{-8} \mathrm{dpa} / \mathrm{s}$. The temperature varied from $371-389^{\circ} \mathrm{C}$. The temperature, dose, and dose rate of the reflector samples also depended on location in the core. Doses were calculated from reactor fluence using NJOY flux-to-dpa cross sections.

For samples in which microstructure and microchemistry were analyzed, the irradiation history is provided in Table 1 . The row 14 subassembly was moved once during its lifetime but spent the majority of time in row 14. While in position 14E10, samples were within $5^{\circ} \mathrm{C}$ of their average temperature. During the short period of time in position $8 \mathrm{~F} 4$, the temperature was $390^{\circ} \mathrm{C}$. Immersion density, grain boundary composition measurements, and microstructural characterization were performed on all four conditions except for SURV $10 \mathrm{~K}-5$ on which no grain boundary composition measurements were performed.

Table 1-Sample History for TEM samples

\begin{tabular}{|c|c|c|c|c|c|c|c|}
\hline Sample & $\begin{array}{l}\text { Reactor } \\
\text { Grid } \\
\text { Position }\end{array}$ & $\begin{array}{l}\text { Time in } \\
\text { Grid } \\
\text { Position } \\
\text { (MWD) }\end{array}$ & $\begin{array}{c}\text { Dose Rate } \\
(\mathrm{dpa} / \mathrm{s}) \text { in } \\
\text { Grid } \\
\text { Position }\end{array}$ & $\begin{array}{c}\text { Average } \\
\text { Dose } \\
\text { Rate } \\
(\mathrm{dpa} / \mathrm{s}) \\
\end{array}$ & $\begin{array}{c}\text { Dose } \\
\text { (dpa) in } \\
\text { Grid } \\
\text { Position }\end{array}$ & $\begin{array}{l}\text { Total } \\
\text { Dose } \\
\text { (dpa) }\end{array}$ & $\begin{array}{c}\text { Avg } \\
\text { Temp } \\
\left({ }^{\circ} \mathrm{C}\right)\end{array}$ \\
\hline $\begin{array}{c}\text { Refl Row } \\
14\end{array}$ & $\begin{array}{c}8 \mathrm{~F} 4 \\
14 \mathrm{E} 10\end{array}$ & $\begin{array}{c}5951 \\
348584\end{array}$ & $\begin{array}{l}2.9 \times 10^{-7} \\
1.5 \times 10^{-8}\end{array}$ & $2.0 \times 10^{-8}$ & $\begin{array}{l}2.4 \\
7.6\end{array}$ & 10 & 379 \\
\hline $\begin{array}{c}\text { Refl Row } \\
10\end{array}$ & $10 \mathrm{C} 2$ & 187505 & $4.7 \times 10^{-8}$ & $4.7 \times 10^{-8}$ & 12.2 & 12.2 & 378 \\
\hline $\begin{array}{c}\text { SURV } \\
\text { Row } 12 \\
\text { K-5 }\end{array}$ & $12 \mathrm{E} 8$ & 215110 & $3.1 \times 10^{-8}$ & $3.1 \times 10^{-8}$ & 8.9 & 8.9 & 375 \\
\hline $\begin{array}{c}\text { SURV } \\
\text { Row } 12 \\
\text { K-6 }\end{array}$ & $12 \mathrm{E} 8$ & 215110 & $6.6 \times 10^{-8}$ & $6.6 \times 10^{-8}$ & 19.6 & 19.6 & 389 \\
\hline
\end{tabular}


Samples were taken from three different lots of 304 stainless steel. Because the subassemblies were fabricated from different lots of steel, differences in composition may be critical. Compositions from the SURV samples were measured prior to insertion in the reactor. Unirradiated archive material exists for the row 10 subassembly, but not for the row 14 subassembly. Therefore, composition was determined from samples taken from both irradiated hex ducts using Inductively Coupled Plasma-Atomic Emission Spectroscopy (ICP-AES) for major elements and a LECO IR-412 Carbon Determinator for carbon. Table 2 provides composition measurements for each hex duct and for the SURV samples. The row 10 subassembly has a significantly smaller concentration of Mo.

Table 2-Typical Compositions for Microchemistry Samples

\begin{tabular}{cccc}
\hline Element & $\begin{array}{c}\text { Row 10 Subassembly } \\
\text { (at. \%) }\end{array}$ & $\begin{array}{c}\text { Row 12 SURV } \\
\text { (at. \%) }\end{array}$ & $\begin{array}{c}\text { Row 14 Subassembly } \\
\text { (at. \%) }\end{array}$ \\
\hline $\mathrm{Cr}$ & 19.6 & 19.4 & 19.6 \\
$\mathrm{Ni}$ & 8.5 & 9.4 & 9.1 \\
$\mathrm{Fe}$ & 69.8 & 68.4 & 69.0 \\
$\mathrm{Mo}$ & $<0.02$ & 0.12 & 0.07 \\
$\mathrm{Mn}$ & 0.82 & 0.90 & 1.01 \\
$\mathrm{C}$ & 0.4 & 0.4 & 0.5 \\
$\mathrm{Si}$ & 0.92 & 1.3 & 0.76 \\
\hline
\end{tabular}

\section{Results}

Immersion density and transmission electron microscopy measurements were performed on samples from rows 10,12 , and 14 . The density and void distribution measurements are presented first followed by the grain boundary segregation measurments.

\section{Density and Void Distributions}

In figure 3, swelling is plotted as a function of dose for both the row 12 surveillance samples and the row 10 and 14 subassembly samples. The swelling of the surveillance samples increases continually with increasing dose, reaching $2 \%$ by 19.6 dpa. For samples irradiated to doses near $10 \mathrm{dpa}$, the swelling increases for samples taken farther from the core center (irradiated at lower displacement rate). 
Figures 4 and 5 show micrographs and void size distributions for the row 10, 12, and 14 samples irradiated to a dose near $10 \mathrm{dpa}$. The swelling increases with decreasing dose rate (larger row numbers). The row 14 sample (lowest dose rate) has a higher density of larger voids and a more symmetrical distribution about the average. The row 12 and 10 samples have a similar average void size, but the row 12 sample has a larger density of voids. The row 10 and 12 samples have a positive skew with a tail of large void sizes up to about $30 \mathrm{~nm}$.

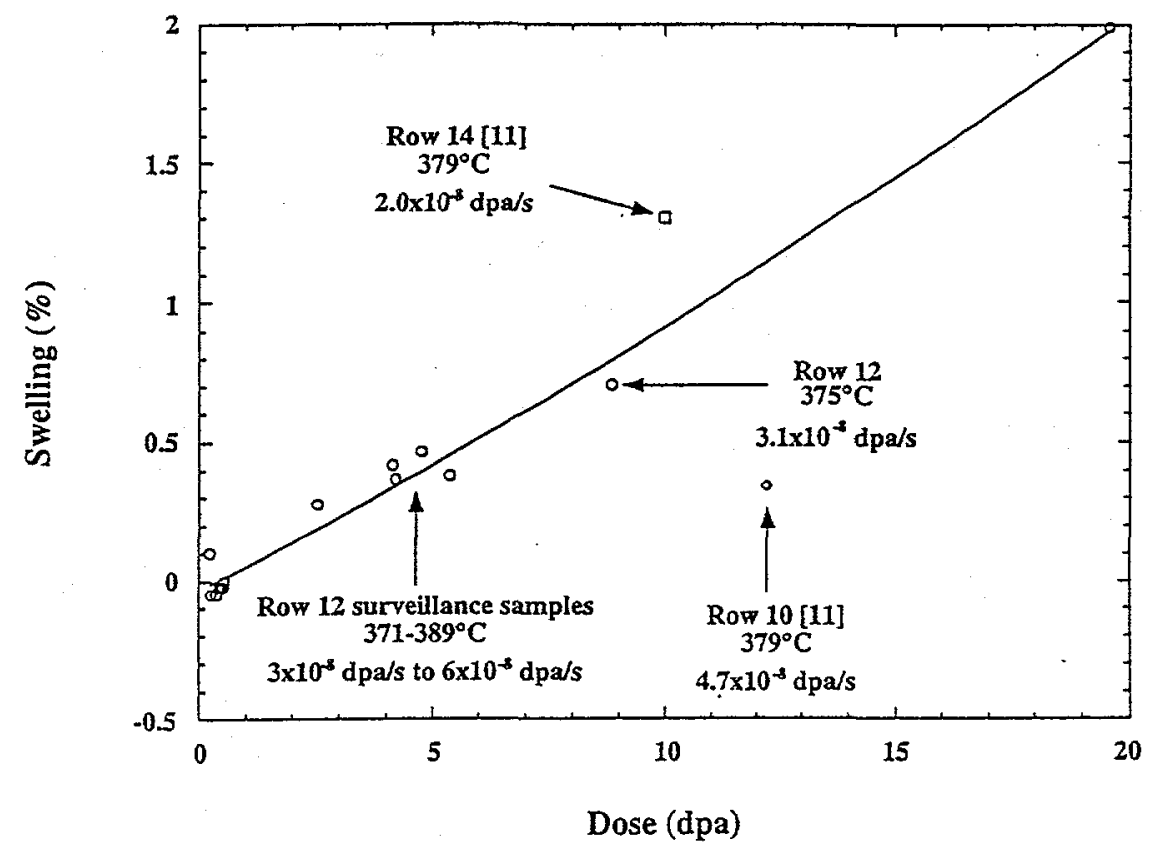

Figure 3-Swelling as a function of dose for samples taken from Row 10,12, and 14.

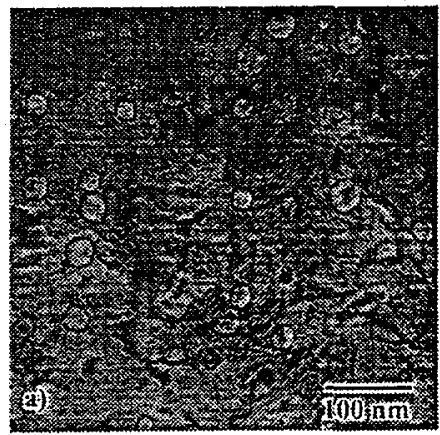

Row 14

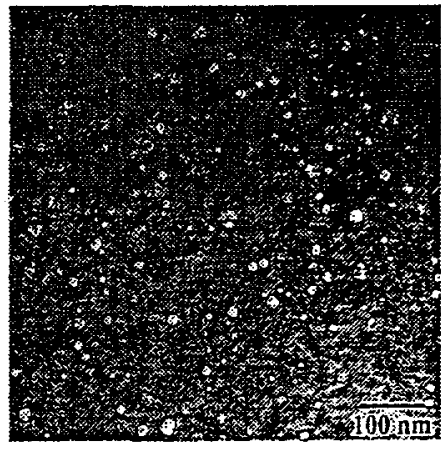

Row 12

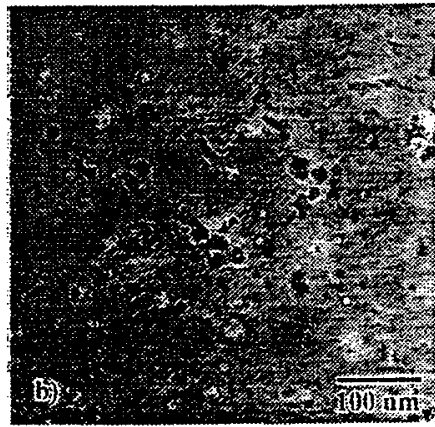

Row 10

Figure 4-Micrographs of voids in samples row 10,12, and 14. 

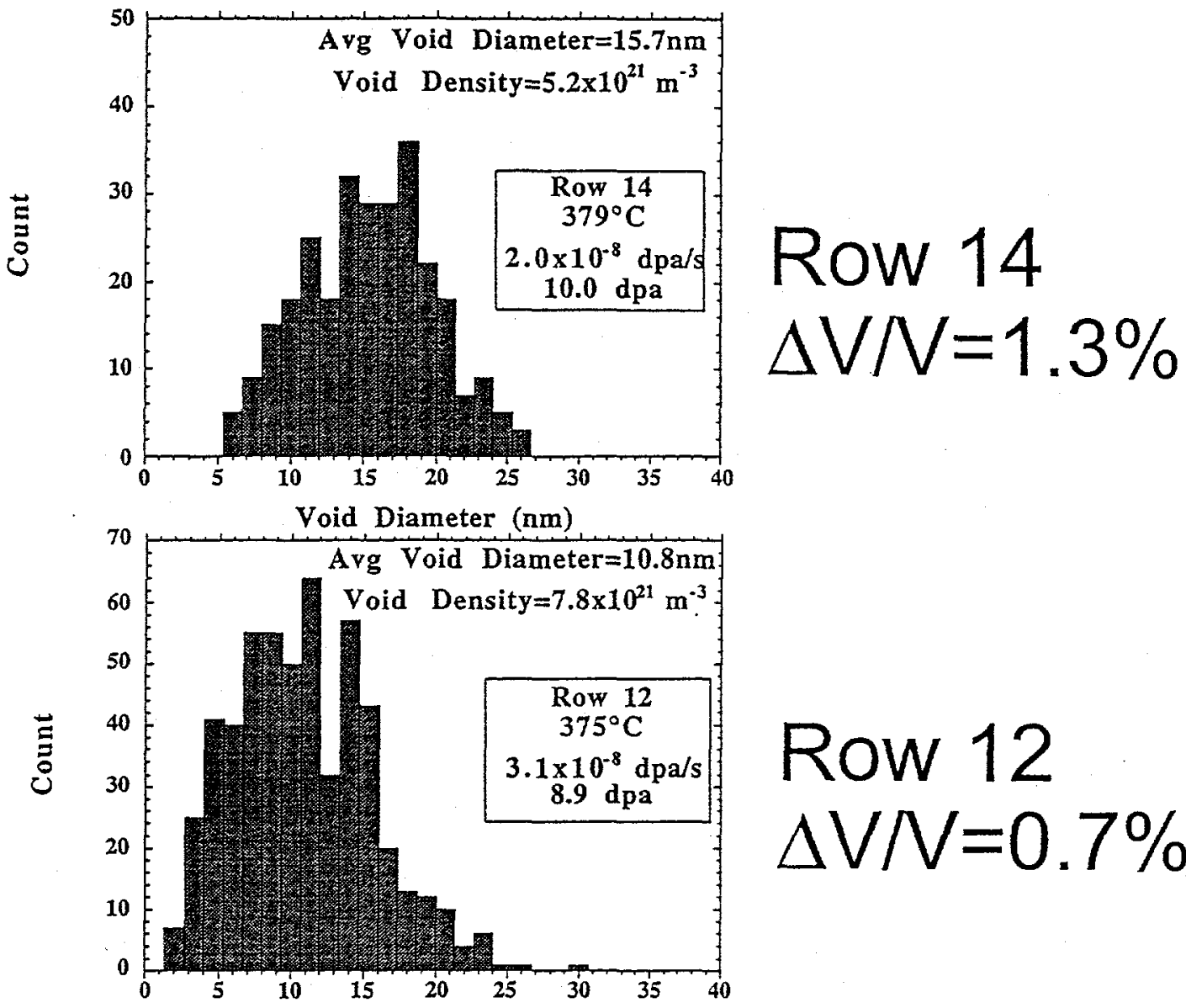

Row 12
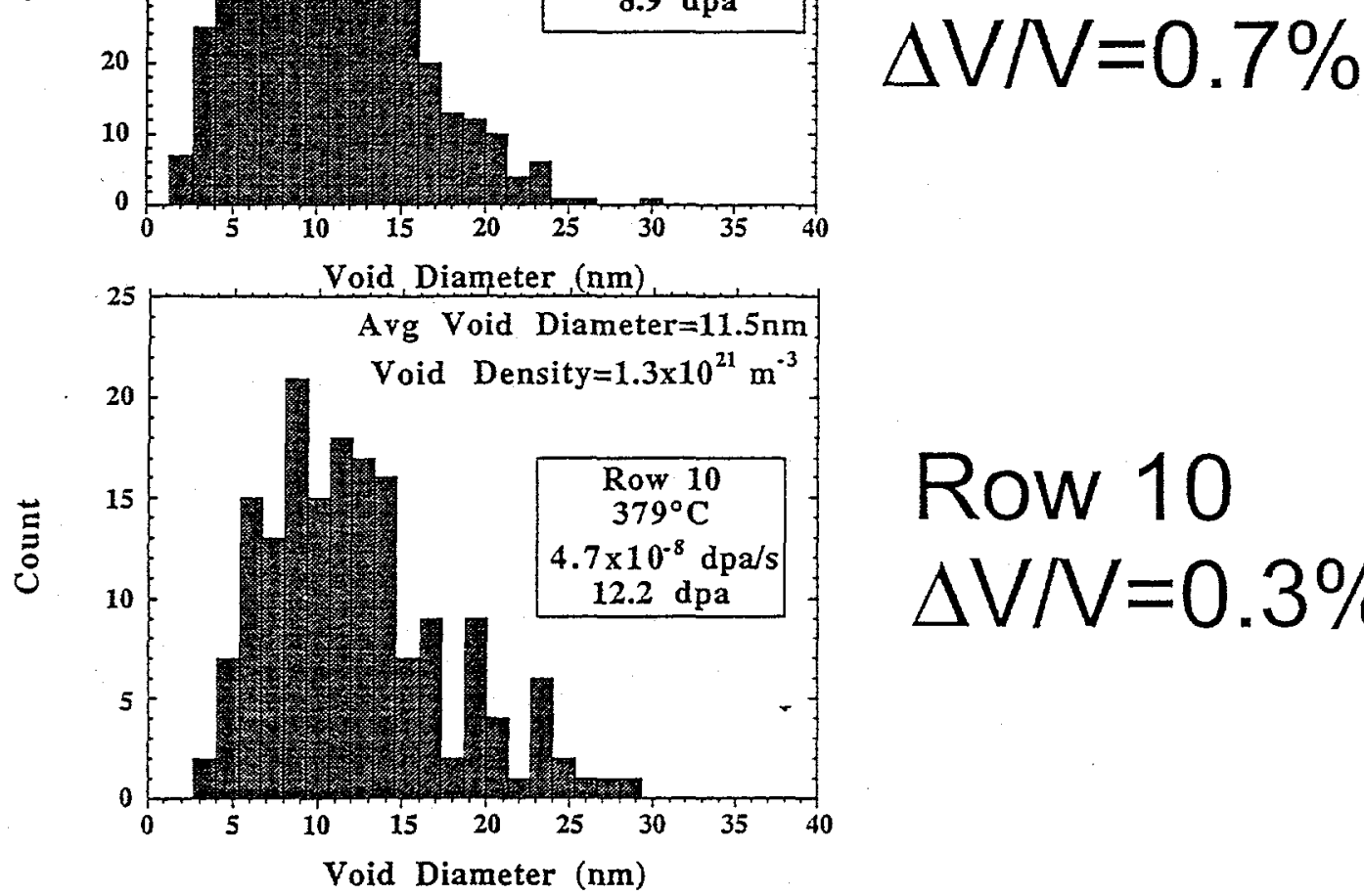

Row 10 $\Delta \mathrm{V} / \mathrm{V}=0.3 \%$

Figure 5-Void size distributions for samples row 10,12, and 14. $\Delta V / V$ is the swelling measured using immersion density 

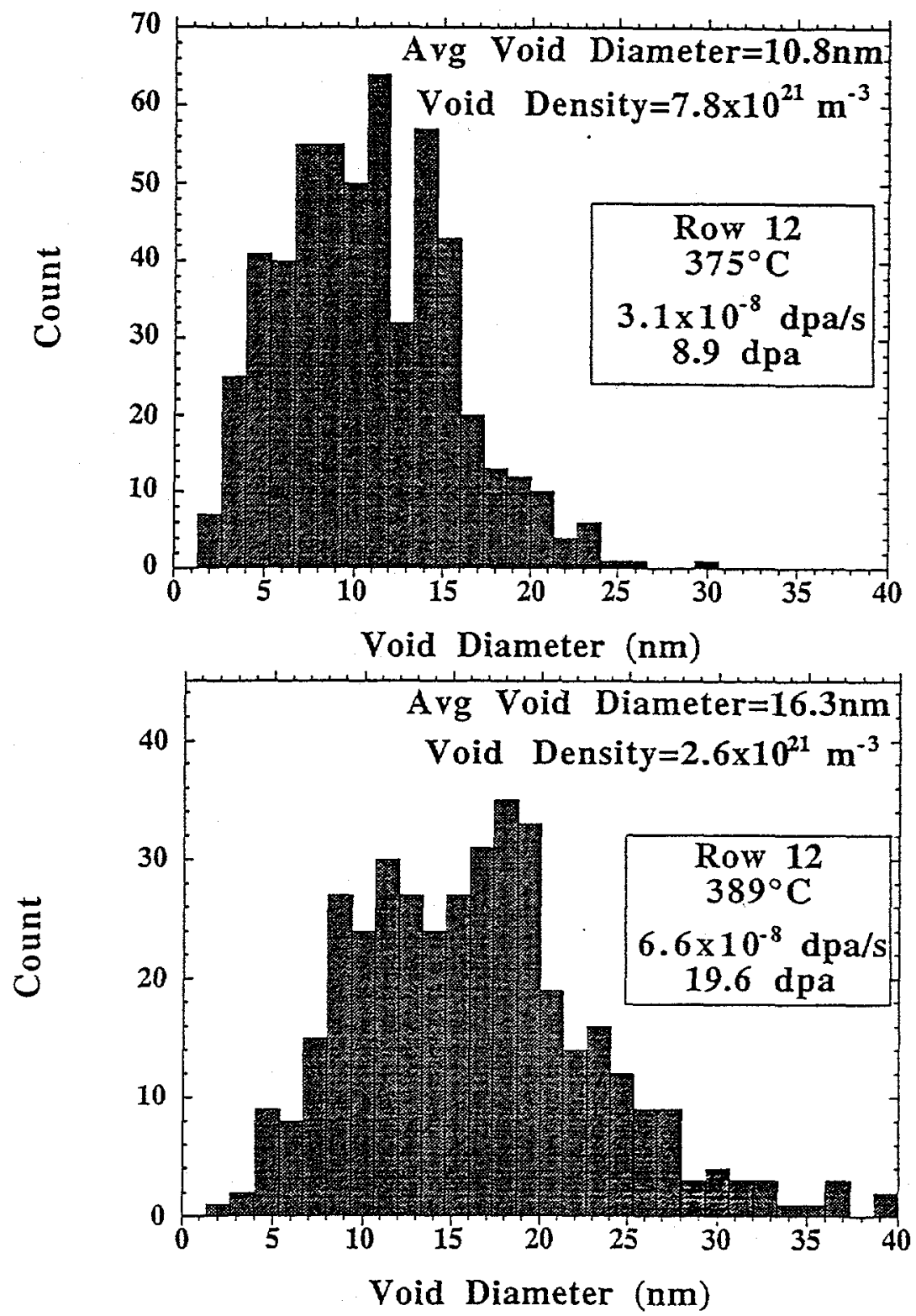

Figure 6-Void size distributions for samples in row 12 .

Void size distributions for the two SURV samples irradiated in row 12 are shown in Figure 6. These samples are from the same lot of steel and were irradiated in the same experimental subassembly, but at different axial heights. The higher dose sample was irradiated closer to the core centerline and experienced about twice the dose. The higher dose sample was also irradiated at a slightly higher temperature. For the sample irradiated to a larger dose and higher temperature, the average void size is larger and the density of 
voids is smaller. The void distribution in the higher dose sample has a larger tail of large voids.

Radiation-induced Grain Boundary Segregation

Figure 7 indicates the change in grain boundary concentration for row 10 (12.2dpa), row 12 (19.6 dpa), and row 14 (10.0 dpa) samples. As the displacement rate decreases, the amount of nickel enrichment and chromium depletion increases. Even at half the dose, the row 14 sample has greater radiation-induced segregation (RIS) of Ni and $\mathrm{Cr}$ than the row 12 sample.

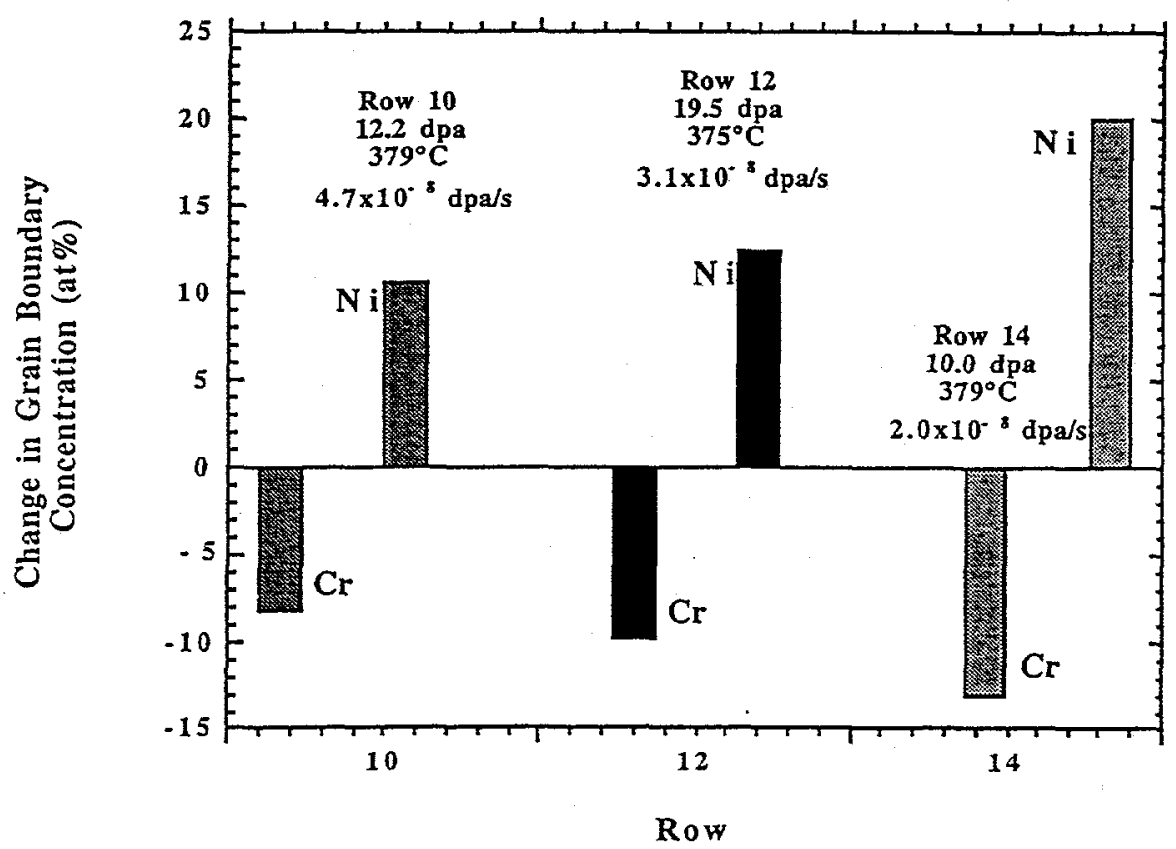

Figure 7-Radiation induced grain boundary segregation in samples from rows 10,12, and 14.

Figures 8 and 9 show the grain boundary segregation for two different boundaries in the row 12 high dose ( $19.6 \mathrm{dpa}$ ) sample. In figure 8, the segregation was measured near a precipitate. The precipitate was a $\mathrm{Cr}$ rich precipitate with a $\mathrm{Cr}$ concentration of 30 at\%. Near the precipitate, the $\mathrm{Cr}$ concentration is lower than at grain boundary locations farther from the precipitate. Away from the boundary, the $\mathrm{Cr}$ is $13-14$ at $\%$. The $\mathrm{Ni}$ concentration is very high nearest the precipitate and lower away from the precipitate. 


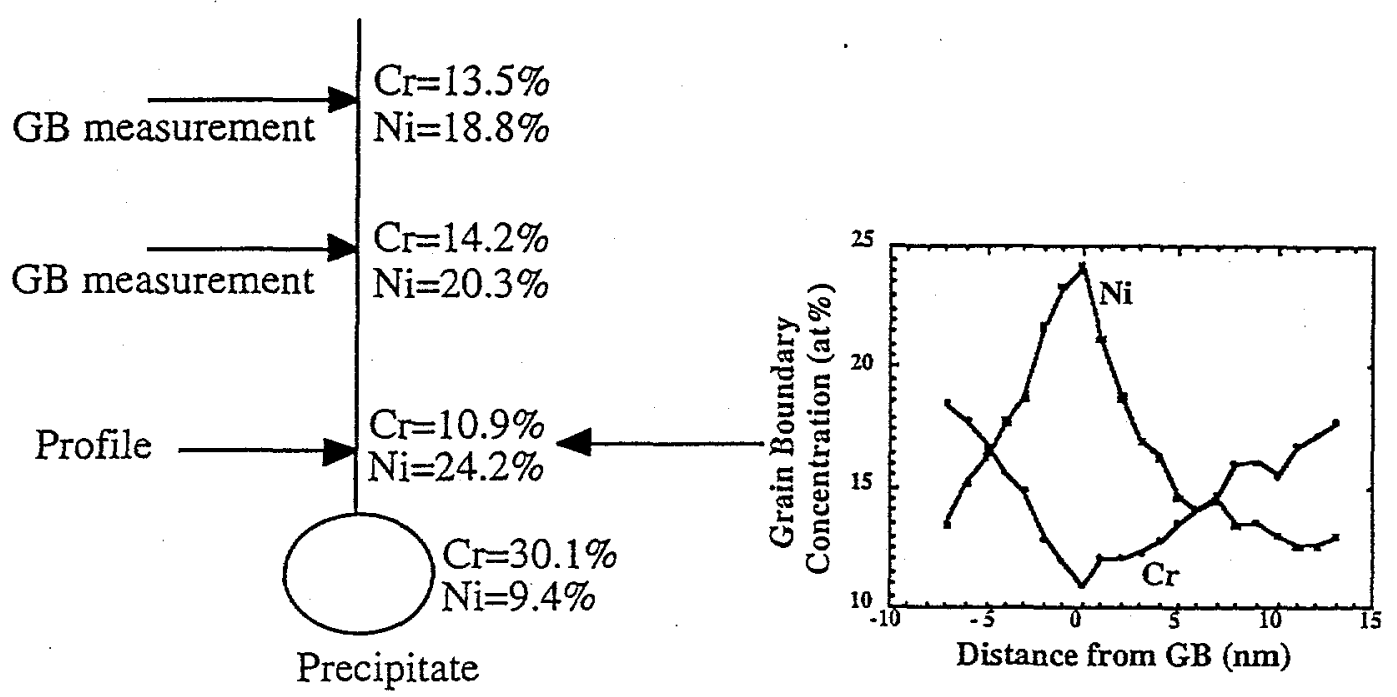

Grain Boundary near Precipitate

Fig 8-Grain boundary segregation near a precipitate for a row 12 sample

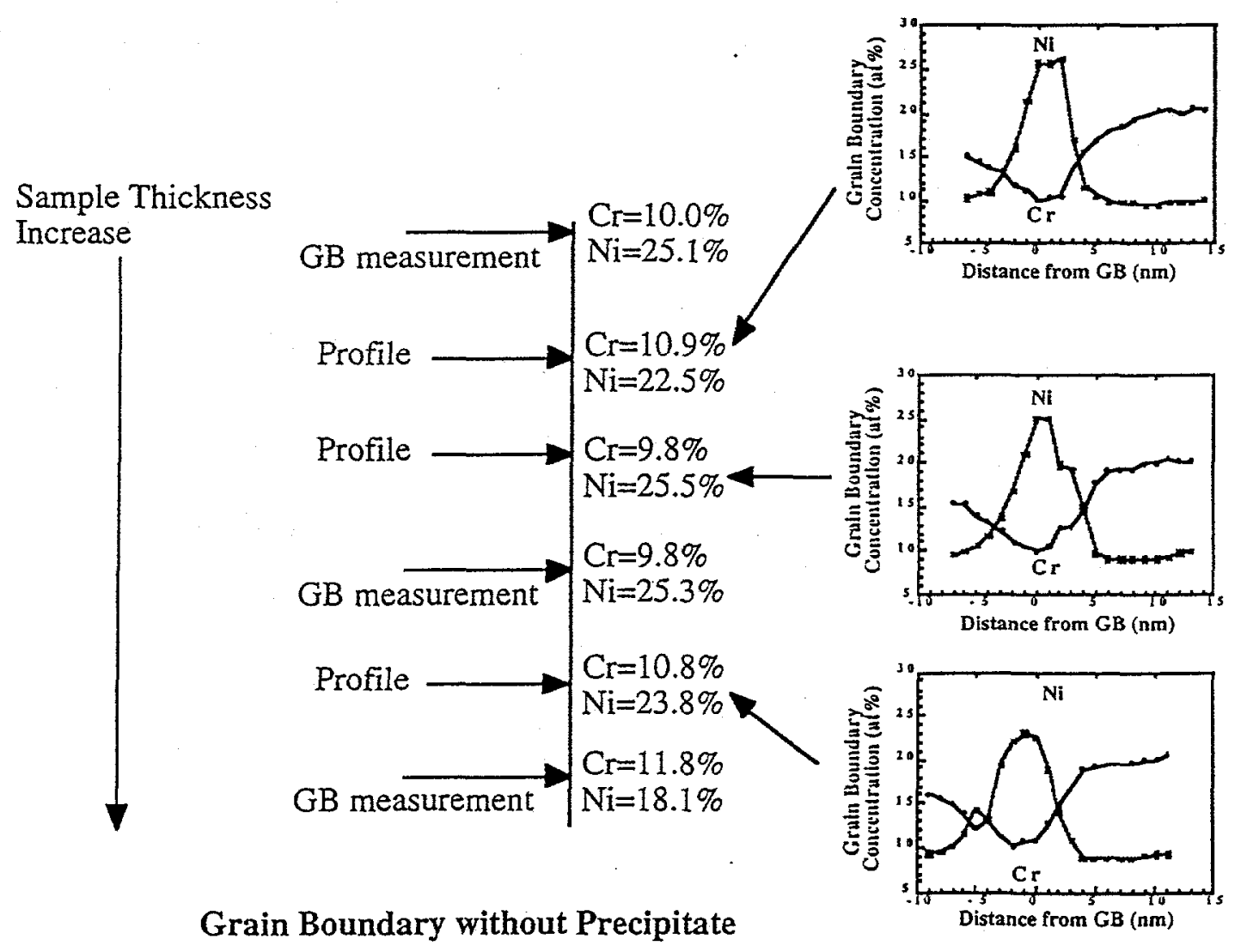

Fig 9-Grain boundary segregation in a precipitate-free area for a row 12 sample 
Figure 9 shows the grain boundary profiles and measurements on a precipitate free boundary in the row 12 high dose (19.6 dpa) sample. The concentrations of $\mathrm{Ni}$ and $\mathrm{Cr}$ are relatively constant. Only the measurement in the thickest area of the sample shows noticeably lower $\mathrm{Ni}$ concentrations.

\section{Discussion}

The implications of irradiation conditions on the swelling and RIS in 304 stainless steel are discussed below.

Swelling

Figure 3 showed the swelling of the EBR-II surveillance material as a function of dose. The swelling reached a maximum of $2 \%$ at $19.6 \mathrm{dpa}$. Austenitic stainless steel alloys eventually reach a terminal swelling rate of $1 \% / \mathrm{dpa}$ [10]. At the maximum dose analyzed (19.6 dpa), the 304 SURV material is still early in the transient portion of the swelling versus dose with a swelling rate near $0.1 \% / \mathrm{dpa}$.

The effect of dose rate on swelling can be seen by noting the relative swelling of the row 10,12 , and 14 samples. For samples irradiated near $375^{\circ} \mathrm{C}$ and $10 \mathrm{dpa}$, swelling increases with decreasing dose rate. The row 14 and row 10 density measurements have been previously reported by Gamer et al. [11], who, in a much larger study, showed a clear dependence of swelling on dose rate in 304 stainless steel.

The differences in void size distribution between the two row 12 samples (figure 6) are likely to be due to both temperature and dose. Void size is known to increase with increasing dose and the larger dose sample has greater swelling. Increasing the temperature is known to increase the void size and decrease the density. The higher temperature sample has larger voids and a smaller density.

\section{Radiation-induced Grain Boundary Segregation}

The discussion of radiation-induced segregation is divided into two sections. First, the effect of dose rate on segregation is explained. Next, the effect of grain boundary precipitation on segregation is discussed. 


\section{Effect of Dose Rate}

Theory predicts that radiation-induced grain boundary segregation depends on both temperature and dose rate. Figure 10 plots model predictions for chromium depletion in 304 stainless steel. At temperatures around $375^{\circ} \mathrm{C}$, chromium depletion should increase with decreasing dose rate. The data from figure 7 confirms this trend.

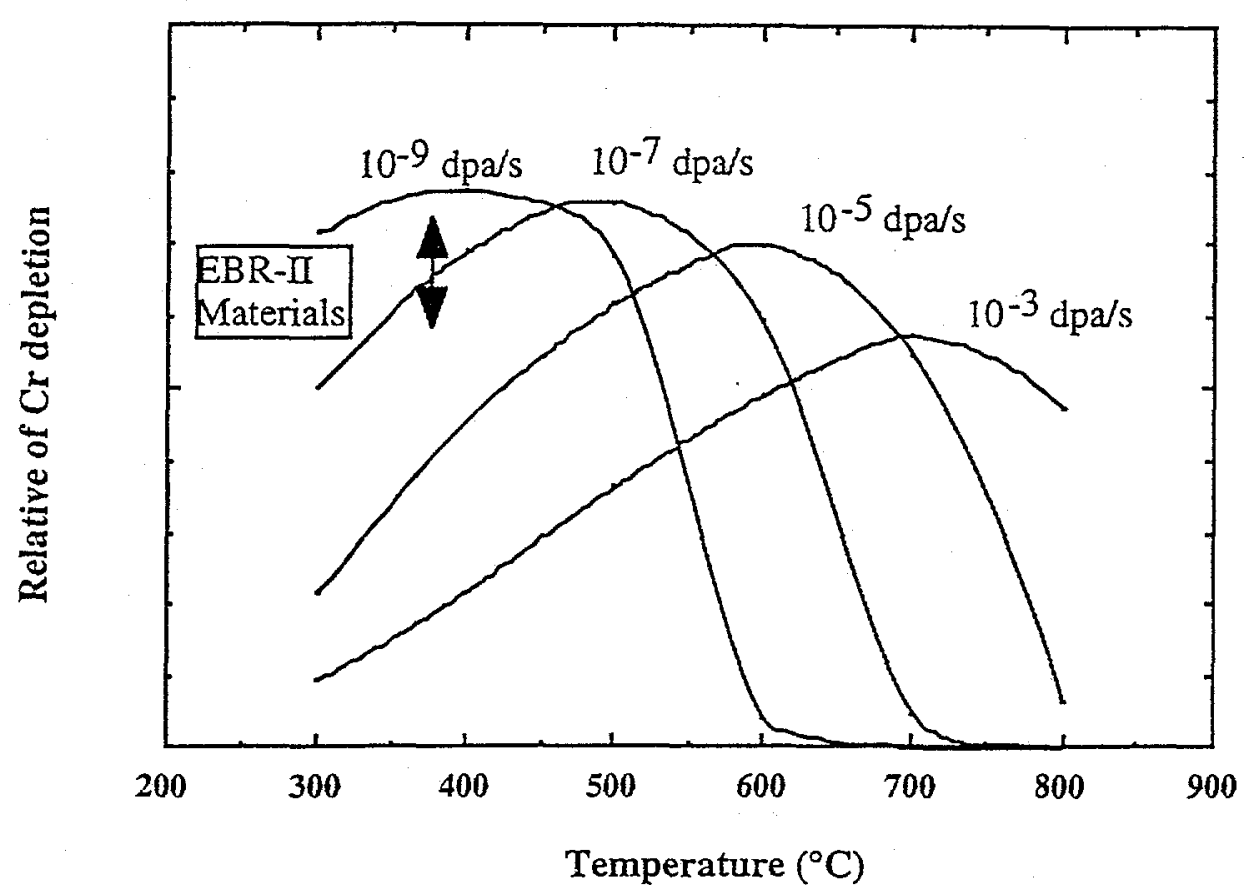

Figure 10-As the dose rate decreases, the maximum grain boundary segregation is expected to occur at a lower temperature. The dose rate shift is approximately $50^{\circ} \mathrm{C}$ for each order of magnitude difference in dose rate.

The row 12 and 14 samples have significantly greater molybdenum than the row 10 sample. Segregation measurements in samples from Magnox reactor control rods (a 4 wt. \% boron steel) irradiated at temperatures from $290-330^{\circ} \mathrm{C}$ to doses from $0.04-0.35$ dpa, indicated that increasing Mo content reduced the $\mathrm{Cr}$ depletion [12]. In the EBR-II samples, greater grain boundary chromium depletion occurs in the sample with greater bulk molybdenum concentration, contrary to the Magnox measurements. Examining Table 2 , the differences in segregation do not correlate with any changes in bulk composition. Since the differences in chromium depletion in the EBR-II materials do not correlate with differences in bulk composition, they are likely to be caused by dose rate differences. 


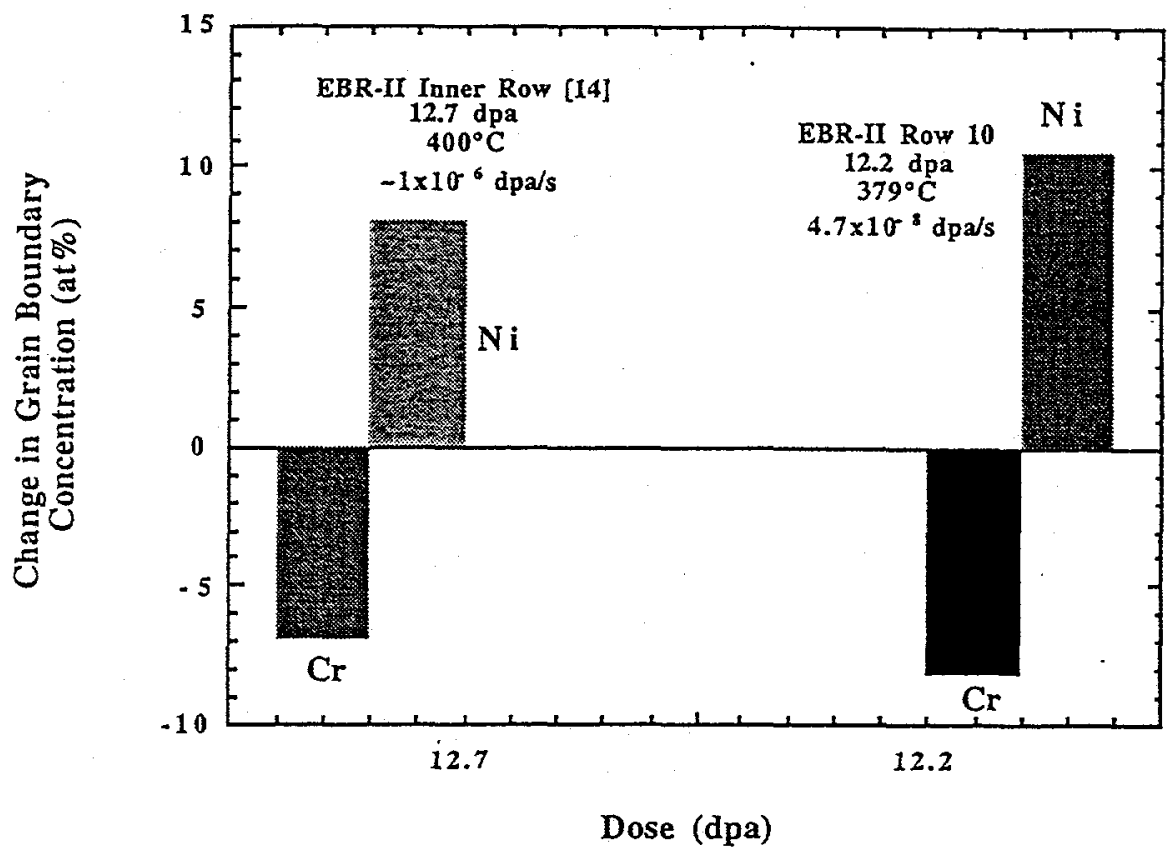

Figure 11-Comparison of Grain Boundary Segregation between inner row and outer row samples irradiated in EBR-II.

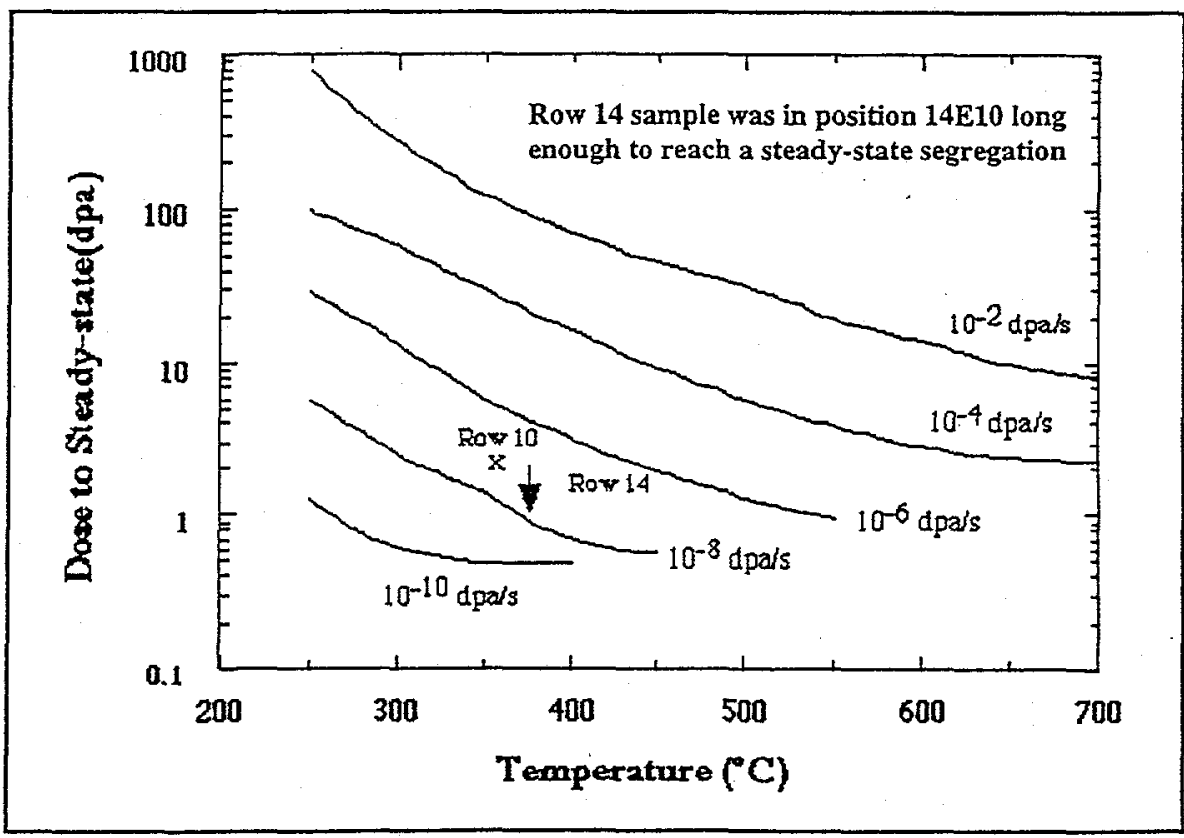

Figure 12-Calculations indicate that even though the row 14 sample was moved once during its exposure, the RIS should have reached steady-state in the final position 
Dumbill measured segregation in an Fe-18Cr-15Ni alloy irradiated with neutrons at $400^{\circ} \mathrm{C}$ to $12.7 \mathrm{dpa}$ in EBR-II [13]. A dose rate was not reported, but a typical experimental location in EBR-II had dose rates on the order of $10^{-6} \mathrm{dpa} / \mathrm{s}$. The segregation measured by Dumbill is compared to the segregation measured in this study in figure 11 . The segregation is larger in the lower dose rate samples. In the work by Dumbill, the Fe$18 \mathrm{Cr}-15 \mathrm{Ni}$ alloy has a greater bulk nickel concentration and therefore would be expected to exhibit greater nickel enrichment [14] for similar irradiation conditions. The greater segregation in the EBR-II materials is likely attributable to a dose rate difference.

The sample in row 14 was moved once during its lifetime, obtaining 7.6 of its total 10 dpa in row 14. Figure 12 shows the calculated time to steady-state RIS for different dose rates and temperatures. For the row 14 dose rate of $2 \times 10^{-8} \mathrm{dpa} / \mathrm{s}$ at $375^{\circ} \mathrm{C}$, RIS should reach steady-state by around 1-2 dpa. Since the row 14 sample received $7.6 \mathrm{dpa}$ in position 14, it should be at steady-state and comparisons with row 12 and 10 samples are not likely to be affected by the sample movement.

\section{Effect of Precipitation}

As seen in figure 8, the existence of a precipitate affects the grain boundary segregation. Near the precipitate, the $\mathrm{Cr}$ concentration is lower as diffusion of $\mathrm{Cr}$ to the precipitate reduces the $\mathrm{Cr}$ on the boundary. The composition near grain boundary precipitates has a noticeable effect on electropolished samples. The $5 \%$ perchloric acid/95\% methanol polishing solution tends to etch away precipitates and the surrounding regions. Heavily precipitated samples may be more susceptible to grain boundary corrosion.

\section{RIS and Void Swelling}

For irradiation temperatures near $375^{\circ} \mathrm{C}$, both the void swelling and radiationinduced grain boundary segregation increase with decreasing dose rate. The decreased dose rate reduces the fraction of point defects lost to recombination, allowing more to participate in diffusional events that lead to RIS or void formation and growth. Although the enrichment of slow diffusing nickel and depletion of fast diffusing chromium at the void surface reduces the subsequent flux of vacancies to the void surface [15], the major factor affecting void growth is the displacement rate. 


\section{Conclusion}

Both void swelling and radiation-induced segregation have been measured in 304 stainless steel irradiated in the EBR-II reactor. For temperatures near $375^{\circ} \mathrm{C}$, a dose of 20 dpa causes $2 \%$ swelling. At 20 dpa, the swelling is still in the transient phase with a rate of about $0.1 \% / \mathrm{dpa}$. At temperatures near $375^{\circ} \mathrm{C}$, both void swelling and RIS increase as the dose rate decreases. Precipitation on the grain boundary can significantly affect the radiation-induced grain boundary segregation profiles in the vicinity of the precipitate.

\section{Acknowledgments}

The authors gratefully acknowledge the efforts of M. E Vaughn, J. P. Webb, E. L. Wood, and the staffs at the Hot Fuels Examination Facility and Analytical Laboratory at ANL-West. Thanks to K. N. Grimm and K. A. Bunde for performing dose calculations and to $R$. T. Jensen for performing the temperature calculations. Work supported under contract W-31-109-Eng-38 with the Department of Energy. Research partially supported by the Division of Materials Sciences, U. S. Department of Energy under contract DEAC05-96OR22464 with Lockheed Martin Energy Research Corp., and through the SHaRE Program under contract DE-AC05-76OR00033 with Oak Ridge Associated Universities.

\section{References}

[1] IAEA-TECDOC-1119

[2] Shah, V. N. and MacDonald, P. E., Aging and Life Extension of Major Light Water Reactor Components, (Elsevier, Amsterdam, 1993).

[3] Andresen, P.L., Ford, F.P., Murphy, S.M., and Perks, J.M., Proc. 4th Int. Symp. on Environmental Degradation of Materials in Nuclear Power Systems - Water Reactors, Jekyll Island, GA, August 1989 (NACE, Houston, 1990), p. 1.

[4] Van Duysen, J. C., Todeschini, P., and Zacharie, G., Effects of Radiation on Materials: 16th International Symposium, ASTM STP 1175, A. S. Kumar, D. S. Gelles, R. Nanstad, and E. A. Little, Eds., (American Society for Testing and Materials, Philadelphia, 1993), p. 747.

[5] Greenberg, S., ANL-7624, Sept 1969

[6] Greenberg, S., Strain, R. V., and Ebersole, E. R., ANL-7682, June 1970

[7] Greenberg, S., Strain, R. V., and Ebersole, E. R., ANL-7937, Sept 1972 
[8] Ruther, W. E., Hayner, G. O., Carlson, B. G., Ebersole, E. R., and Allen T. R., "The EBR-II Materials-Surveillance Program: Part IV. Results Of SURV-4 and SURV6," ANL-98/3, January, 1998

[9] Ruther, W. E., Staffon, J. D., Carlson, B. G., and Allen, T. R., "The EBR-II Materials-Surveillance Program: Part IV. Results Of SURV-5," ANL-98/4, March, 1998

[10] Garner, F. A., Materials Science and Technology: A Comprehensive Treatment, Volume 10a, pp. 419-543, VCH Publishers (1994).

[11] Bond, G.M, Sencer, B. H., Garner, F.A., Hamilton, M.L., Allen T.R., and Porter., D.L., "Void swelling of annealed 304 stainless steel at $\sim 370-385^{\circ} \mathrm{C}$ and PWRrelevant displacement rates", submitted to the Proceedings of the Ninth International Symposium on Environmental Degradation of Materials in Nuclear Power SystemsWater Reactors, August 1999, Newport Beach, CA (1999)

[12] Spellward, P., Walmsley, J., Scowen, R., Partridge, N., Stump, J., Corcoran, R., Gilmour, T., and Callen, V., Proc. 8th Int. Symp. on Environmental Degradation of Materials in Nuclear Power Systems - Water Reactors, Amelia Island, Fl, August 1997 (American Nuclear Society, LaGrange Park, IL, 1997), p. 734.

[13] Dumbill, S. and Williams, T.M., in: Proceedings of the Conference on Materials for Nuclear Reactor Core Applications, Vol. I (BNES London 1987) p. 119

[14] Allen, T. R., Busby, J. T., Was, G. S., and Kenik, E. A., J. Nucl. Mater. 255,44 (1998).

[15] Allen, T.R., Busby, J.T., Gan, J., Kenik, E. A., and Was, G.S., "The Correlation Between Swelling and Radiation-Induced Segregation in Fe-Cr-Ni Alloys," Effects of Radiation on Materials: $19^{\text {th }}$ International Symposium, ASTM STP 1366, M. L. Hamilton, A. S. Kumar, S. T. Rosinski, and M. L. Grossbeck, Eds., American Society for Testing and Materials, West Conshohocken, PA, 2000, pp. 739-755. 